\title{
Agents of restorative justice?
}

\section{Probation officers in the child justice system}

\section{THULANE GXUBANE}

Thulane.Gxubane@uct.ac.za

Probation officers, like generic social workers, have been and continue to be implementers rather than generators of social policies. Yet, probation officers have an important role to play in transforming the child justice system as they are central to the administration of child justice. This article argues that the Child Justice Bill (B49 of 2002) needs to be aligned with other pieces of legislation and policies that reflect a developmental approach and response to crime. The developmental approach will not only maximise the opportunities for meaningful interventions that could translate into prevention of crime and recidivism among young offenders, but will also have long-term benefits for the young offenders, their victims and society in general.

This article examines the role of probation officers in the transformation and administration of the child justice system in South Africa, with a specific focus on assessments and sentencing. The discussion will shed light on some of the major challenges associated with probation practice in the current and proposed child justice system in South Africa. The concept of restorative justice as a proposed philosophical and legislative framework for working with young offenders is also discussed in an attempt to challenge the bifurcation of offences ${ }^{1}$ - which seems to be informed by the general misconception that diversion and restorative justice is inappropriate in dealing with youth sex offences.

In this paper the word young is used interchangeably with the word child, referring to any person under 18 (Constitution of the Republic of South Africa, 1996). Within this age group, different pieces of legislation make specific provisions with regard to age restrictions, type of offences and circumstances surrounding the offence. A child offender would for example qualify as suitable for conversion to a children's court inquiry, or for a first or second or third level of diversion, or for sentencing to a reformatory school, and so on.

This article was inspired by the author's recent submissions to the Justice and Constitutional Development Portfolio Committee on behalf of the Department of Social Development, University of Cape Town, during the public hearings on the re-drafted 2007 Child Justice Bill (B49 of 2002).

\section{PROBATION OFFICERS AND POLICY DEVELOPMENT}

Responsibility and social justice were identified by Konopka (1972) as key values that should inform the social work profession. As probation is a 
discipline emanating from social work, probation practitioners need to uphold and promote those values. However, social justice as a core value can only be realised when probation practitioners recognise that they are not only professionally responsible to the offender that they seek to help, but also to the victim, and society in general.

Contributing to social policy is a primary role of probation practitioners, particularly to those policies that relate to their daily practice. Pincus and Minahan (1972) theorised that the purpose of social work is changing people; linking people with resources; changing the environment; and contributing to development and modification of social policy. Probation officers offer a wealth of knowledge and insight based on their experience in working with young offenders and their families. Sadly, such contributions have not been forthcoming in South Africa.

By failing to participate in policy development, probation officers are missing a valuable opportunity to positively influence other roleplayers and policy-makers. Moreover, they are playing no part in decisions that closely affect them as social workers. It is suggested that this situation can be addressed by increasing the number of probation officers in the NGO and government sectors, and providing them with resources and incentives that will encourage and enable them to contribute to research, advocacy and policy development.

\section{PROBATION OFFICERS AND THE ADMINISTRATION OF CHILD JUSTICE}

\section{Assessment}

Assessment is defined in Chapter 1 of the 2007 version of the Child Justice Bill as the 'assessment of a child by a probation officer as contemplated in Chapter 5'. Chapter 5 in turn outlines the different purposes of assessment, which are to:

(a) establish whether a child may be in need of care for purposes of referring the child to a children's court in terms of section 51 or 64; (b) estimate the age of the child if the age is uncertain;

(c) gather information relating to a previous conviction, any previous diversion or any pending charge in respect of the child;

(d) formulate recommendations regarding the release or detention and placement of the child;

(e) where appropriate, establish the prospects for diversion of the matter;

(f) in the case of a child below the age of ten years or a child referred to in section 9(1)(c)(ii), establish what measures need to be taken in terms of section 7;

(g) in the case of a child aged ten years or older but below 14 years, express a view on the factors contemplated in section 9(1)(b) that may affect the criminal capacity of such child as contemplated in section 10; or

(h) provide any other relevant information regarding the child which the probation officer may regard in the best interests of the child or which may further any objective which this Act intends to promote or achieve.

The danger of this administrative approach to assessment is that it is likely to lead probation officers, especially novice practitioners, to merely performing the administrative tasks of the courts as outlined from (a) to (g) above. While it is essential for probation officers to provide support services to the courts it is equally important that they keep sight of the overall developmental mandate of the country relating to crime prevention. The function of assessment is to inform and guide therapeutic interventions that will help the child offender not to come into conflict with the criminal justice system again. Probation officers may not be in a position to provide the rehabilitation services themselves, but they need to be aware of various services and programmes that the child can be referred to.

In a submission made by the author to the Justice and Constitutional Development Portfolio Committee, reference was made to the fact that a lot of work has already been done in the development and amendment of different pieces of legislation (such as the Probation Services 
Amendment Act 35 of 2002) to ensure that they are aligned with the developmental framework adopted by the state some years ago. Therefore it stands to reason that the Child Justice Bill should be harmonised and aligned with other pieces of legislation that reflect the developmental frame of reference. For example, the Probation Services Act No. 116 of 1991 states that assessment is:
a process of developmental assessment or evaluation of a person, the family
circumstances of the person, the nature and circumstances surrounding the alleged commission of an offence, its impact on the victim, the attitude of the alleged offender in relation to the offence and any other relevant factor.

\section{Sentencing}

In their daily practice, probation officers are involved in the sentencing of child offenders. They are responsible for guiding the court to alternative sentencing options through their presentence investigations. Alternative sentences hold offenders accountable for their unlawful actions while giving them the opportunity to change their behaviour. But for alternative sentences to be effective they need to be accompanied by strict conditions and elements of restorative justice practices.

There are three practical challenges facing probation officers and other justice officials with regard to sentencing: poor and incompetent presentence investigations; a shortage of skilled social workers; and a strong orientation towards punishment by the courts. Each of these is addressed in some detail below.

\section{Poor and incompetent pre-sentence investigations} Magistrates frequently complain about the poor quality of, and gaps in, some probation officers' pre-sentencing reports. This seems to be a matter of insufficient training. In a study that investigated the training needs of probation officers in the Western Cape it was found that a profound lack of self-esteem among probation officers was due to an inadequately delivered probation service, particularly the pre-sentence reports (Graser and de Smidt 2007). These researchers concluded that this is directly linked to social workers' lack of adequate training in probation work (Graser \& de Smidt 2007).

In South Africa, any person registered with the South African Council of Social Services Professions as a social worker can be employed as a probation officer (PO). Yet Graser (2006) asserts that probation work is a specialised field of service that requires much specialised knowledge, skills and qualities in the person who performs it. Training in social work alone does not necessarily qualify a person to act as a PO. Whilst training in social work is necessary, a PO needs further training in certain aspects of the criminal law and procedures, criminology, treatment of offenders, the objectives of punishment, and the structure, functioning and psychology of the criminal justice courts.

A probation officer is a professional considered by the court of law as an 'expert witness'. The key elements of expertise are skills, knowledge and experience. As pointed out by Graser (2006), presentence investigations and report writing requires knowledge in theories and the objectives of punishment, knowledge of legislation (such as the Criminal Procedures Act) that guides sentencing, particularly of convicted children and knowledge of a range of alternative sentencing options.

Apart from occupation-specific training, a $\mathrm{PO}$ requires certain personal qualities that are even more important than academic training. These include personal maturity and emotional strength; the ability to be firm and realistic; sound judgment; and warmth and understanding (Graser 2006).

\section{Shortage of skilled social workers}

In an attempt to address the delay in the finalisation of cases involving young offenders, due to a shortage of social workers to act as probation officers, Section 72 of the re-drafted Child Justice Bill makes provision for someone other than a social worker or probation officer to prepare a pre-sentence report (Section $72(1)(a)$ ). There is a real need to find alternatives to deal 
with the shortage of social workers to act as probation officers, as it often leads to unconstitutional delays in the sentencing of convicted child offenders. The Justice and Constitutional Portfolio Committee was cautioned against this approach. It was proposed that such duties need to be performed by probation officers or persons with post-graduate training in probation and correctional practice for example, the Honours or Masters qualification in Probation and Correctional Practice, as offered by the Department of Social Development at the University of Cape Town and the Departments of Social Work at the University of the Free State and University of Johannesburg. This is because a person who compiles a pre-sentence report needs to know the legislative framework and principles guiding sentencing of child and youth offenders. An appropriate sentence needs to be carefully considered, as it will have a long lasting impact, not only to the child offender, but also to the victim and society in general. A sentence therefore needs to be realistic and take into account the interests of all the parties affected by the criminal offence committed by the child.

\section{Orientation of the courts towards punishment}

Social workers working as probation officers often report that magistrates do not take their reports seriously, and rarely consider their recommendations.

Fatima Chohan, chairperson of the parliamentary committee on justice and constitutional development was reported in the Cape Argus as saying:

(I)t is unlikely that the Bill would be passed by the end of the year (2007)... the committee had sent the Bill back for redrafting so that it could be divided into categories of minor and serious offences.... even when the Bill was passed, a lack of capacity and structures could hamper its implementation. A lack of social workers to act as probation officers, as well as a shortage of places of safety for children were some of the constraints that would be faced.

However, the major delay in the enactment of the Child Justice Bill (CJB) seemed not only to relate to a lack of human and material resources, but also to its emphasis on and orientation towards punishment. For example, one of the most striking features of the 2007 re-drafted CJB, which was criticised by many, was the bifurcation of child offenders. The re-drafted CJB excluded certain child offenders from the possibility of diversion, based on the nature of the offences they committed rather than the unique circumstances surrounding each offence. Yet it has been pointed out by many scholars, including Batley and Maepa (2005:16), that 'applying harsher punishment to offenders has been shown internationally to have little success in preventing crime'.

Imprisonment has long-lasting and devastating effects on young offenders, and the community in general. When young offenders are eventually released back to the community on completion of their prison terms they have been negatively affected by their institutional experience. Therefore a restorative approach to sentencing of young offenders needs to be considered as an alternative.

\section{RESTORATIVE JUSTICE}

A focus on the philosophy underlying restorative justice is very important, because it has implications for practice. And the practice of restorative justice will to a large extent be influenced and shaped by how people conceptualise it.

Kurki and Pranis (cited in Skelton and Batley, 2006:7) proposed the following questions as pointers in evaluating whether a process or programme is restorative in nature or not:

1. Does it address harms and causes?

2. Is it victim oriented?

3. Are offenders encouraged to take responsibility?

4. Are all three stakeholder groups involved?

5. Is there an opportunity for dialogue and participatory decision-making?

6. Is it respectful to all parties?

Skelton and Batley (2006) argued that it may not be possible or even desirable for every restorative 
justice programme or process to address all six questions, but might possibly include some of them. Restorative justice has to be conceptualised as 'an approach, a mindset, or a way of thinking about justice' rather than a particular process or programme. Zehr (cited in Skelton and Batley, 2006:7) argued that it is becoming important to talk about what is not restorative as to define what it is', and supported a restorative justice continuum framework that can be used to assess whether processes are more or less restorative in nature. Some processes will be fully restorative, others will be pseudo or non-restorative, others may be partially and potentially restorative along the continuum (Zehr cited in Skelton and Batley, 2006).

Batley (2005:31) provides a comprehensive response to the question of whether restorative justice is appropriate in dealing with serious offences. He states that:

Applying restorative justice principles and processes in rape and murder cases does not imply minimizing the seriousness and tragedy of such incidents, nor does it suggest that perpetrators should be left off the hook simply because they have apologized. Serious cases present excellent opportunities for victims to feel that they are heard, and for perpetrators to be confronted with the real consequences of their actions. Specific steps can also be taken to ensure that victims are not dealt with insensitively, as restorative justice seeks to promote the respect and dignity off all concerned, especially those who have been hurt.

In a study conducted in central Johannesburg on victims' views regarding a desirable response to criminals, the results, surprisingly, indicated that the public might be more reasonable than politicians believe when it comes to the treatment of offenders (Leggett, 2005). The study showed that victims were not as single-mindedly retributive as many would believe, particularly considering that the area experiences one of the highest crime rates in South Africa. Although many victims expressed a desire for vengeance, they also consistently expressed an interest, across offence types, in telling the offender how they felt. Leggett (2005) therefore concludes that his findings support the belief that victims in South Africa are open to creative and restorative approaches to resolving crime.

In another study that explored challenges and opportunities for restorative justice in the Western Cape from the perspectives of victims and perpetrators of youth crime, Shearar (2005) found that most victims and perpetrators welcomed the notion of restorative justice as a means of dealing with criminal cases involving young offenders.

Skelton and Batley (2006) argued that the assessment of whether a case is suitable for invoking restorative justice options should not only focus on the seriousness of the offence but also on the circumstances surrounding the offence. Cases in which there is an identifiable victim are all suitable for restorative justice (Skelton and Batley, 2006). The fact that restorative justice is available across the system is also an important factor in understanding that it can be applied to serious offences (Skelton and Batley, 2006). Even where the offender has served a part or all of his or her prison term, restorative justice can still be part of the resolution.

In research that was conducted by Gantana (2006), exploring the implementation of restorative justice by magistrates, prosecutors and probation officers in sentencing of young offenders in the Western Cape, the researcher found that her respondents were familiar with the concept of restorative justice and its value. However she noticed in the charge sheets that the justice officials still preferred the traditional way of sentencing. She interpreted this to mean that her respondents did not completely believe in the benefits that restorative justice would offer to the parties involved. She concluded that a holistic approach that involves the victim, offender and community, with more interdisciplinary cooperation between different role players, in the application of restorative justice to sentencing would be ideal. 


\section{CONCLUSION}

This article has highlighted the importance of the often-neglected role of a probation officer in policy development. It is argued that it is the probation officer who will help other role-players and policy-makers understand what the probation profession seeks to achieve in its work with child offenders, their victims and their families. The article also argues that a restorative justice framework should underpin all legislation that relates to the management of child offenders in South Africa. Some progress has been made with regard to the integration of the restorative justice approach in both statutory and therapeutic interventions in South Africa. An increasing number of courts are beginning to insist that each pre-sentence report needs to be accompanied by a victim impact report. Whilst this is commendable this author believes that by adopting the restorative justice approach in both statutory and therapeutic interventions, the victims of crime need to be brought into the picture right from the beginning and throughout the statutory process.

\section{REFERENCES}

Batley, M 2005. Restorative Justice in the South African context. In Beyond Retribution: Prospects for Restorative Justice in South Africa. ISS Monograph Series (111). Pretoria: Institute for Security Studies and Restorative Justice Centre.

Batley, M and Maepa, T 2005. Introduction. In Beyond Retribution: Prospects for Restorative Justice in South Africa. ISS Monograph Series (111). Pretoria: Institute for Security Studies and Restorative Justice Centre.

Child Justice Bill, B49-2002. Project Committee on Juvenile Justice, Pretoria.

Constitution of the Republic of South Africa, 1996. Constitutional Assembly, Cape Town.

Fatima, C 2007. Five years on, kids in jail wait for justice. Cape Argus, 11 April.

Gantana, K 2006. The implementation of restorative justice by magistrates, prosecutors and probation officers in sentencing of young offenders at selected district magistrate courts in the Western Cape. (Unpublished Masters thesis, University of Cape Town).

Graser, R and Smidt, S 2007. Training needs of Probation Officers: Views of Selected Probation Officers in the Western Cape. Unpublished research report, The Provincial Department of Social Development:
Western Cape in association with the Department of Social Development: University of Cape Town.

Graser, R 2006. Probation Practice in South Africa. Forthcoming book. University of Cape Town.

Konopka, G 1972. Social Group Work: A Helping Process. New Jersey: Prentice-Hall, Inc.

Leggett, T 2005. Justice versus retribution: Attitudes to punishment in the Eastern Cape. In ISS Monograph Series (45). Pretoria: Institute for Security Studies.

Mazibuko, F 1996. Social Workers and Social Policy: Related Functions and Skills in Practice. Social Work/ Maatskaplike Werk, 1996:32 (1):148-161.

Pincus, A and Minahan, A 1972. Social Work Practice: Model and Method. Itasca, Illinois: F.E. Peacock Publishers.

Probation Services Amendment Act 35 of 2002. Pretoria: Government Printer.

Shearar, A 2005. A new approach to child justice? Exploring challenges and opportunities for restorative justice in the Western Cape from the perspectives of victims and perpetrators of youth crime. Masters thesis, University of Cape Town.

Skelton, A and Batley, M 2006. Charting progress, mapping the future: restorative justice in South Africa. Pretoria: Restorative Justice Centre and Institute for Security Studies.

\section{ENDNOTE}

1 Bifurcation refers to a policy of separating out the minor offenders from the serious offenders with the intention of being tough on the latter. 